\title{
Simulasi Pengaruh Variasi Konduktor Berkas Terhadap Gangguan Berisik Dan Radio Interferensi Pada Saluran Udara Tegangan Ekstra Tinggi 275kV
}

\author{
Sonong ${ }^{1 *}$, Herman Nawir ${ }^{2}$, Fitrawati Suharti ${ }^{3}$, Insan Kamil ${ }^{4}$ \\ 1,2,3,4 Jurusan Teknik Mesin, Politeknik Negeri Ujung Pandang, Makassar 90245, Indonesia \\ *sonong@poliupg.ac.id
}

\begin{abstract}
The use of extra-high voltage lines can increase efficiency and reduce voltage drop but cause corona generation. Corona that occurs increases channeling losses and causes disruption to the environment in the form of Audible Noise (AN) and Radio Interference (RI). Audible Noise (AN) and Radio Interference (RI) that are too large will disturb the community around the transmission line. The use of a bundle conductor is a way to reduce the risk of corona. This paper discusses the effect of variations in the bundle conductor on noise interference and radio interference in $275 \mathrm{kV}$ extra-high-voltage air lines (SUTET). The types of variations include variations in the number of beams, variations in the distance between sub-conductors, and variations in diameter of the conductor. Next, the Audible Noise (AN) and Radio interference (RI) values are calculated for the Latuppa (Palopo) - Pomana channel planning. The results of the calculation of AN and RI values on SUTET $275 \mathrm{kV}$ are still included as safe criteria because the value is still below the criteria limits of Perry and SPLN 46-1-1981 concerning the Noise Level Limitation Guidelines and the IEEE Radio Noise Design Guide about the maximum limit of RI.
\end{abstract}

Keywords - Audible Noise (AN), Radio Interfernc (RI), bundle conductor

\begin{abstract}
Abstrak-- Penggunaan saluran tegangan ekstra tinggi dapat meningkatkan efisiensi dan meurunkan jatuh tegangan tetapi mengakibatkan timbulnya korona. Korona yang terjadi meningkatkan rugi penyaluran dan menimbulkan gangguan terhadap lingkungan berupa Audible Noise (AN) dan Radio Interference (RI). Audible Noise (AN) dan Radio Interference (RI) yang terlalu besar akan mengganggu masyarakat disekitar saluran transmisi. Penggunaan konduktor berkas merupakan sebuah cara untuk mengurangi resiko terjadinya korona. Paper ini membahas tentang pengaruh variasi konduktor berkas terhadap gangguan berisik dan interferensi radio pada saluran udara tegangan ekstra tinggi (SUTET) $275 \mathrm{kV}$. Adapun jenis variasi meliputi variasi jumlah berkas, variasi jarak antar sub-konduktor, dan variasi diameter konduktor. Yang selanjutnya, dihitung nilai Audible Noise (AN) dan Radio interference (RI) untuk perencanaan saluran Latuppa (Palopo) - Pomana. Hasil perhitungan nilai AN dan RI pada SUTET $275 \mathrm{kV}$ masih masuk kriteria aman karena nilainya masih dibawah batas kriteria Perry dan SPLN 46-1-1981 tentang Pedoman Pembatasan Tingkat Bising dan IEEE Radio Noise Design Guide tentang batas maksimal RI.
\end{abstract}

Kata Kunci-Audible Noise (AN), Radio Interfernc (RI), konduktor berkas

\section{PENDAHULUAN}

Pusat pembangkit tenaga listrik yang berada jauh dari pusat beban membutuhkan saluran transmisi untuk menyalurkan daya listrik. Karena permukaaan tanah yang tidak selalu datar dan kadang saluran transmisi harus melewati bukit-bukit maka saluran udara lebih dipilih daripada saluran bawah tanah [1].

Dalam penyaluran daya listrik akan terjadi rugi daya penyaluran dan jatuh tegangan (voltage drop) yang besarnya sebanding dengan panjang saluran. Penggunaan tingkat tegangan yang lebih tinggi merupakan solusi dari permasalahan tersebut. Namun, jika tegangan terus ditingkatkan akan timbul peristiwa korona [1]. Korona pada saluran transmisi memiliki kemampuan atenuasi (redaman) tersendiri yang berpotensi menimbulkan berbagai gangguan terhadap lingkungan sekitar berupa gangguan komunikasi radio (Radio Inervference) dan gangguan berisik (Audible Noise) [2]. Nilai Audible Noise dan Radio Interference perlu diperhatikan dalam perancangan Saluran Udara Tegangan Ekstra Tinggi (SUTET) karena dikhawatirkan dapat menimbulkan gangguan disekitar area saluran 
transmisi. Untuk mengurangi efek korona ini, dapat dilakukan dengan menggunakan konduktor berkas. Konduktor berkas adalah konduktor yang terdiri dari dua konduktor atau lebih yang dipakai sebagai konduktor satu fasa. Pembentukan konduktor berkas dilakukan dengan cara mendekatkan satu konduktor dengan konduktor lain pada jarak tertentu menggunakan spacer untuk mengurangi rugi-rugi korona [3].

Audible Noise (AN) Gangguan Berisik (Audible Noise) atau sering disingkat dengan AN adalah bunyi yang terdengar terus-menerus baik yang merata, tak teratur serta tidak nyaman didengar oleh indra pendengaran manusia normal yang disebabkan oleh suara mesin industri, transportasi maupun suara akibat korona pada saluran transmisi.

Tingkat $\mathrm{AN}$ diukur dalam satuan $\mathrm{dB}(\mathrm{A})$ yang sesuai dengan satuan pendengaran manusia. Besar AN sebanding dengan peningkatan tegangan saluran [4]. Jarak lateral objek yang akan dievaluasi AN-nya dari kawat konduktor Batas AN menurut kriteria Perry berdasarkan tingkat kenyamanan masyarakat dibedakan menjadi tiga, yaitu:

a. Tanpa teguran : lebih kecil dari $52,5 \mathrm{~dB}(\mathrm{~A})$

b. Teguran sedang : 52,5 sampai $59 \mathrm{~dB}(\mathrm{~A})$

c. Banyak teguran : lebih besar dari $59 \mathrm{~dB}(\mathrm{~A})$

Secara khusus PT. PLN tidak mengeluarkan peraturan mengenai nilai AN pada saluran transmisi. Namun, pada SPLN 46-1 tahun 1981 tentang pembahasan tingkat bising, dapat dijadikan acuan tentang tingkat bising.

Tabel 1. Tingkat Bising menurut SPLN 46-11981

\begin{tabular}{|c|c|c|}
\hline $\begin{array}{c}\text { Kriteria } \\
\text { Pendengaran }\end{array}$ & $\begin{array}{c}\text { Tingkat Bising } \\
(\mathrm{dB}(\mathrm{A}))\end{array}$ & Ilustrasi \\
\hline Menulikan & $100<\mathrm{AN} \leq 120$ & Halilintar, meriam \\
\hline Sangat hiruk & $80<\mathrm{AN} \leq 100$ & Jalan hiruk pikuk, perusahaan sangat gaduh, pluit polisi \\
\hline Kuat & $60<\mathrm{AN} \leq 80$ & Kantor gaduh, jalan pada umumnya, radio, perusahaan \\
\hline Sedang & $40<\mathrm{AN} \leq 60$ & $\begin{array}{c}\text { Rumah gaduh, kantor umumnya, percakapan kuat, radio } \\
\text { pelahan }\end{array}$ \\
\hline Tenang & $20<\mathrm{AN} \leq 40$ & $\begin{array}{c}\text { Rumah tenang, kantor perorangan, auditorium, } \\
\text { percakapan }\end{array}$ \\
\hline Sangat tenang & $0<\mathrm{AN} \leq 20$ & Suara daun-daun, berbisik, batas dengar terendah \\
\hline
\end{tabular}

Kriteria Pendengaran Tingkat Bising dB (A) Menulikan $100<\mathrm{AN} \leq 120$ Sangat Hiruk $80<\mathrm{AN} \leq 100$ Kuat $60<\mathrm{AN} \leq 80$ Sedang $40<\mathrm{AN} \leq 60$ Tenang $20<\mathrm{AN} \leq 40$ [5].

Perhitungan AN dengan Rumus Empiris B.P.A adalah sebagai berikut [6] :

a. Jumlah berkas $\mathrm{n}<3 \mathrm{AN}(\mathrm{i})=120 \log 10 \mathrm{gm}(\mathrm{i})+55 \log 10 \mathrm{~d}-11,4 \log 10 \mathrm{D}(\mathrm{i})-115,4$

b. Jumlah berkas $n \geq 3 \mathrm{AN}(\mathrm{i})=120 \log 10 \mathrm{gm}(\mathrm{i})+55 \log 10 \mathrm{~d}-11,4 \log 10 \mathrm{D}(\mathrm{i})+26,4 \log 10 \mathrm{~N}-128,4$

Keterangan :

AN(i) : AN pada konduktor berkas -i dB(A),

gm(i) : gradien tegangan permukaan konduktor berkas maksimum rata-rata pada tiap fasa i (

$\mathrm{kV} \mathrm{rms/cm),}$

i $\quad: 1,2,3, \ldots . \mathrm{n}$

d : diameter sub-konduktor $(\mathrm{cm})$,

$\mathrm{N}$ : jumlah sub-konduktor pada konduktor berkas,

D(i) : jarak radial fasa (i) ke lokasi yang diamati (m),

$\mathrm{P} \quad$ : total dari jumlah fasa 
141 Sonong, Herman Nawir, Fitrawati Suharti, Insan Kamil. Simulasi Pengaruh Variasi Konduktor Berkas Terhadap Gangguan Berisik Dan Radio Interferensi Pada Saluran Udara Tegangan Ekstra Tinggi 275kV

Rumus AN berdasarkan Program TLCALC 2001 adalah sebagai berikut [7]:

a. Jumlah berkas $n<3$ SLTL50 (i) $=122,68 \log \operatorname{gm}(\mathrm{i})+58,68 \log \mathrm{d}(\mathrm{i})-10,53 \cdot \log \mathrm{D}(\mathrm{i})-122,73$

b. Jumlah berkas $n \geq 3$ SLTL50 $=122,68 \log$ gm(i) $+24,99 \log N$

Keterangan:

$\begin{array}{ll}\text { SLTL50 (i) } & \text { : AN pada konduktor berkas -i dB(A) } \\ \mathrm{d}(\mathrm{i}) & \text { : diameter sub-konduktor }(\mathrm{cm}) \\ \mathrm{N} & \text { : jumlah sub-konduktor pada konduktor berkas } \\ \mathrm{Gm} & \text { : gradien tegangan permukaan konduktor rata-rata }(\mathrm{kV} \mathrm{rms} / \mathrm{cm}) \\ \mathrm{D}(\mathrm{i}) & \text { : jarak radial fasa (i) ke lokasi yang diamati }(\mathrm{m}) \\ \mathrm{P} & \text { : total dari jumlah fasa }\end{array}$

Radio Interference (RI). Besarnya radio interference (RI) seperti halnya audible noise (AN) yaitu yang dipengaruhi oleh gradient tegangan permukaan konduktor, jumlah berkas, diameter konduktor, kondisi atmosfer dan jarak lateral objek yang akan dievaluasi RI-nya dari kawat konduktor serta frekuensi alat pengukuran. Batasan besar RI dapat menggunakan standar IEEE Radio Noise Design Guide yang menetapkan batas nilai tertinggi yaitu $40 \mathrm{~dB} \mu \mathrm{V} / \mathrm{m}$ pada jarak 100 feet atau $30 \mathrm{~m}$ dari fasa konduktor paling luar. Pada kondisi cuaca hujan nilai RI akan meningkat $16-22 \mathrm{~dB} \mu \mathrm{V} / \mathrm{m}[8]$. Perhitungan RI Rumus Cigre adalah sebagai berikut [8]:

$\mathrm{RI}_{\mathrm{i}}=3,5 . \mathrm{E}_{\mathrm{m}}+12 \cdot \mathrm{r}-33 \log _{10}\left(\frac{\mathrm{Di}}{2 \mathrm{O}}\right)-30$

Keterangan :

$\mathrm{Ri}_{\mathrm{i}} \quad$ : Ri pada konduktor i terhadap antena $(\mathrm{db} \mu \mathrm{v} / \mathrm{m})$.

$\mathrm{E}_{\mathrm{m}} \quad$ : Gradien tegangan permukaan konduktor berkas $(\mathrm{kv} \mathrm{rms} / \mathrm{cm})$.

R : Jari-jari sub konduktor $(\mathrm{cm})$.

Di : Jarak antara konduktor i dengan antena $(m)=d=(h 2+r 2), i=1,2,3, \ldots n$.

$\mathrm{H} \quad$ : Ketinggian konduktor i dari tanah $(\mathrm{m})$.

$\mathrm{R} \quad$ : Jarak lateral dari antena ke konduktor i (m).

Perhitungan RI dengan rumus empiris TLCALC 2001 yaitu [6]:

a. RI pada cuaca baik

$\mathrm{RI}_{\mathrm{FL} 50}=-105,81+117,41 \log \mathrm{g}_{\mathrm{m}}(\mathrm{i})+40,38 \log \mathrm{d}+40,38 \log \mathrm{d}+1,54 \log \mathrm{N}-10,22 \log \mathrm{D}(\mathrm{i})$ $-27,10 \log \mathrm{f}$

b. RI pada cuaca hujan

$\mathrm{RI}_{\mathrm{FL}}(\mathrm{i})=-81,98+119,56 \log _{\mathrm{gm}}(\mathrm{i})+43,57 \log \mathrm{d}+3,97 \log \mathrm{N}-19,05 \log \mathrm{D}(\mathrm{i})-25,07 \log \mathrm{f}$

Keterangan :

$\mathrm{RI}_{\mathrm{FL} 50}(\mathrm{i})$ : RI konduktor i terhadap antena $(\mathrm{dB} \mu \mathrm{V} / \mathrm{m})$

$\mathrm{G} \quad$ : Gradien tegangan permukaan konduktor berkas $(\mathrm{kV} \mathrm{rms} / \mathrm{cm})$

D : Diameter sub konduktor $(\mathrm{cm})$

$\mathrm{N} \quad$ : Jumlah berkas

Di : Jarak antara konduktor i dengan antena $(m)=D=\sqrt{(h 2+R 2)}, i=1,2,3, \ldots . n$

$\mathrm{H} \quad$ : Ketinggian konduktor i dari tanah (m)

$\mathrm{R} \quad$ : Jarak lateral dari antena ke konduktor i (m)

F : Frekuensi yang digunakan dalam pengukuran $(\mathrm{MHz})$

GUIDE atau GUI builder merupakan sebuah Graphical User Interface (GUI) yang dibangun dengan obyek grafik seperti tombol (button), kotak teks, slider, menu dan lain-lain. Aplikasi yang 
menggunakan GUI umumnya lebih mudah dipelajari dan digunakan karena orang yang menjalankannya tidak perlu mengetahui perintah yang ada dan bagaimana kerjanya [9].

\subsection{Tempat dan Waktu Pelaksanaan}

\section{METODE PENELITIAN}

Dalam penelitian ini, objek yang akan observasi yakni Jaringan Transmisi, Saluran Udara Tegangan Ekstra Tinggi (SUTET) 275 kV Latuppa-Pomana milik PT. Poso Energy. Penelitian ini diadakan pada bulan Juni hingga Agustus 2019.

\subsection{Tahap Persiapan Penelitian}

1. Studi Literatur Terhadap Objek dan Penelitian

2. Pengumpulan Data

Membuat Program GUI Matlab

3. Melakukan Pengujian

4. Analisis Data

5. Pengambilan Kesimpulan

\section{a) Prosedur Penelitian}

1. Membuat M-File Pada Matlab

2. Membuat jarak radial fasa konduktor

3. Menghitung nilai Audible Noise dan Radio Interference

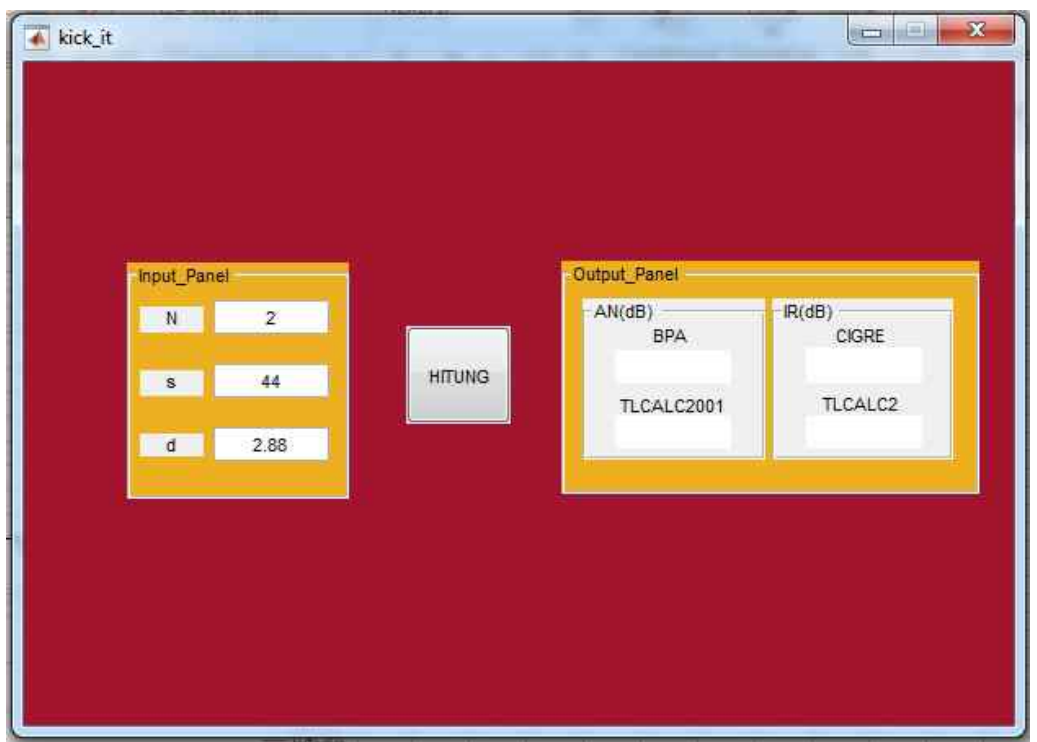

Gambar 1. Layout program penelitian menggunakan program GUI Matlab

Untuk lebih jelasnya, adapun diagram alir dari penelitian yang dilakukan. Mulai dari proses pengumpulan data, analisis data hingga pemograman data sehingga diperoleh kesimpulan pada penelitian ini yaitu sebagai berikut. 
143 Sonong, Herman Nawir, Fitrawati Suharti, Insan Kamil. Simulasi Pengaruh Variasi Konduktor Berkas Terhadap Gangguan Berisik Dan Radio Interferensi Pada Saluran Udara Tegangan Ekstra Tinggi 275kV
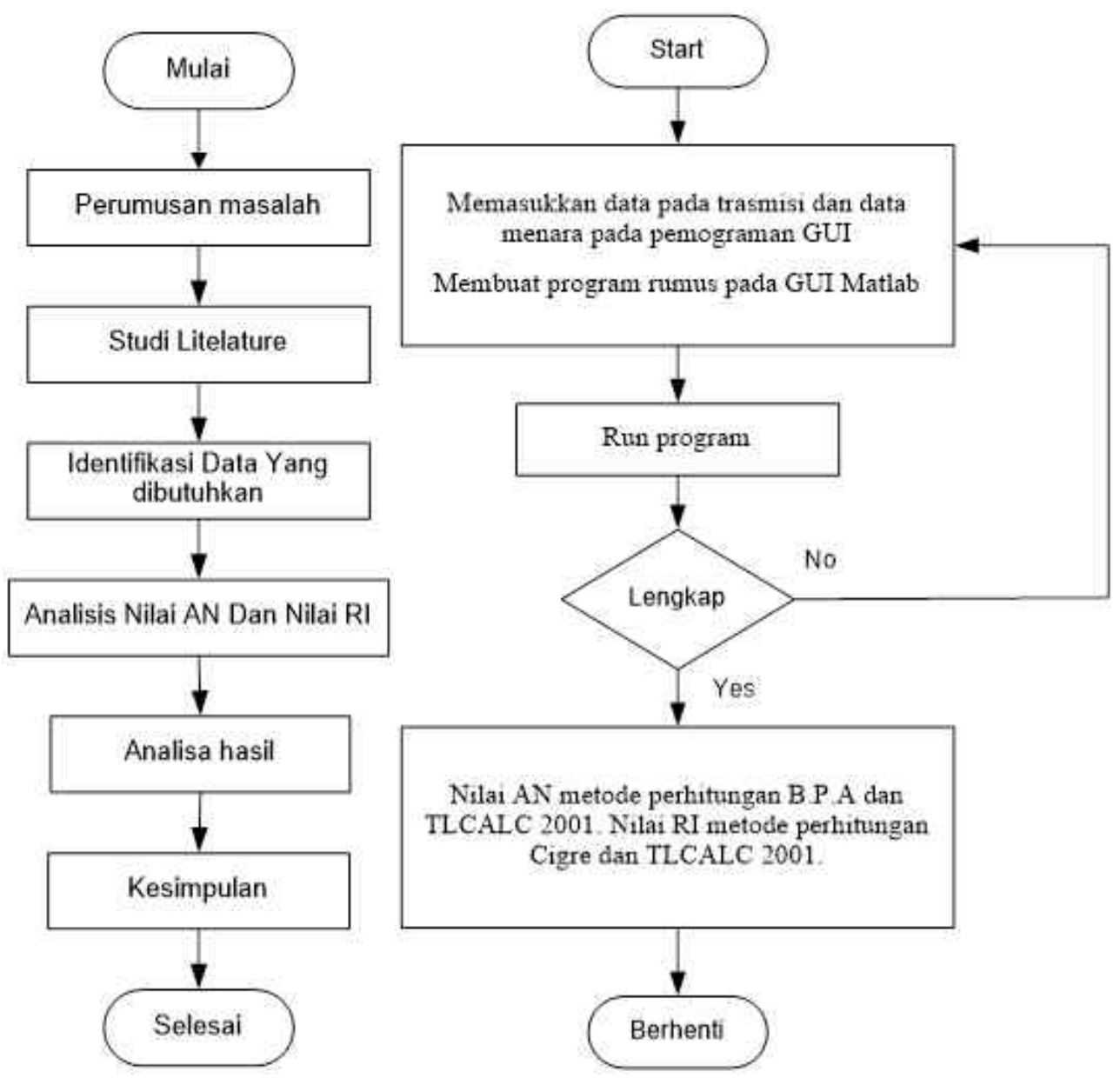

(a)

(b) 


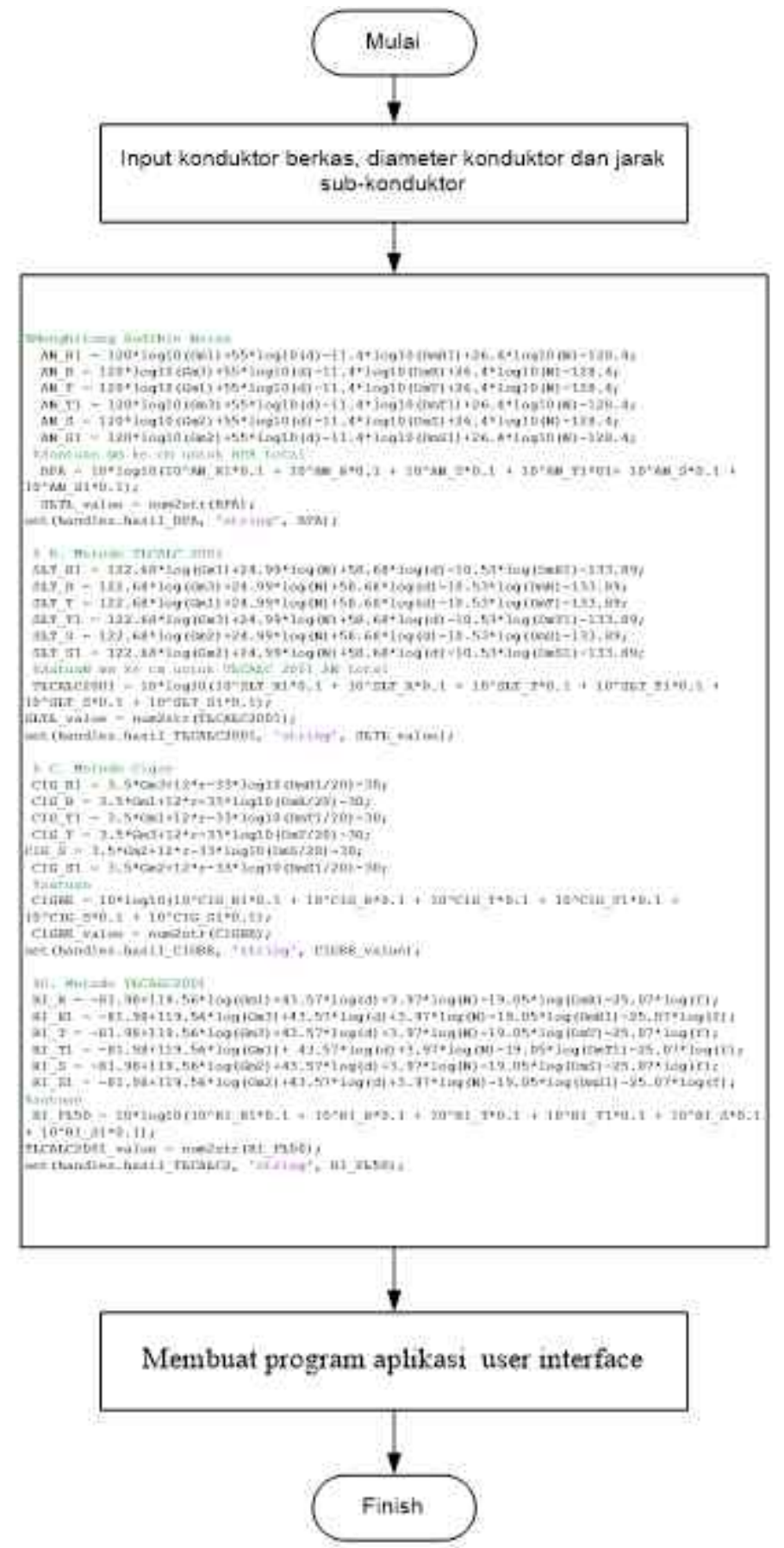

(c)

Gambar 2. Flowchart kegiatan penelitian (a), Flowchart sistem (b), dan Flowchart program (c) 
145 Sonong, Herman Nawir, Fitrawati Suharti, Insan Kamil. Simulasi Pengaruh Variasi Konduktor Berkas Terhadap Gangguan Berisik Dan Radio Interferensi Pada Saluran Udara Tegangan Ekstra Tinggi 275kV

\section{HASIL DAN PEMBAHASAN}

3.1 Hubungan antar jumlah berkas (N) dengan nilai AN dan RI.

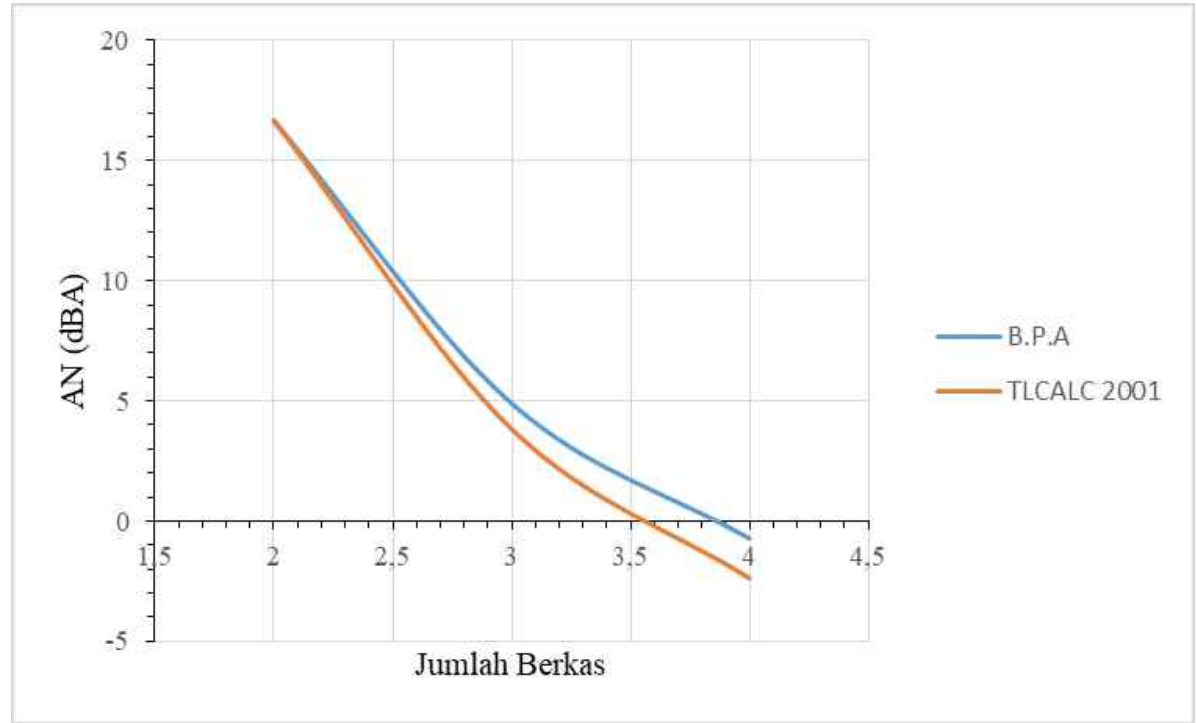

Gambar 3. Hubungan antara jumlah berkas dengan nilai AN

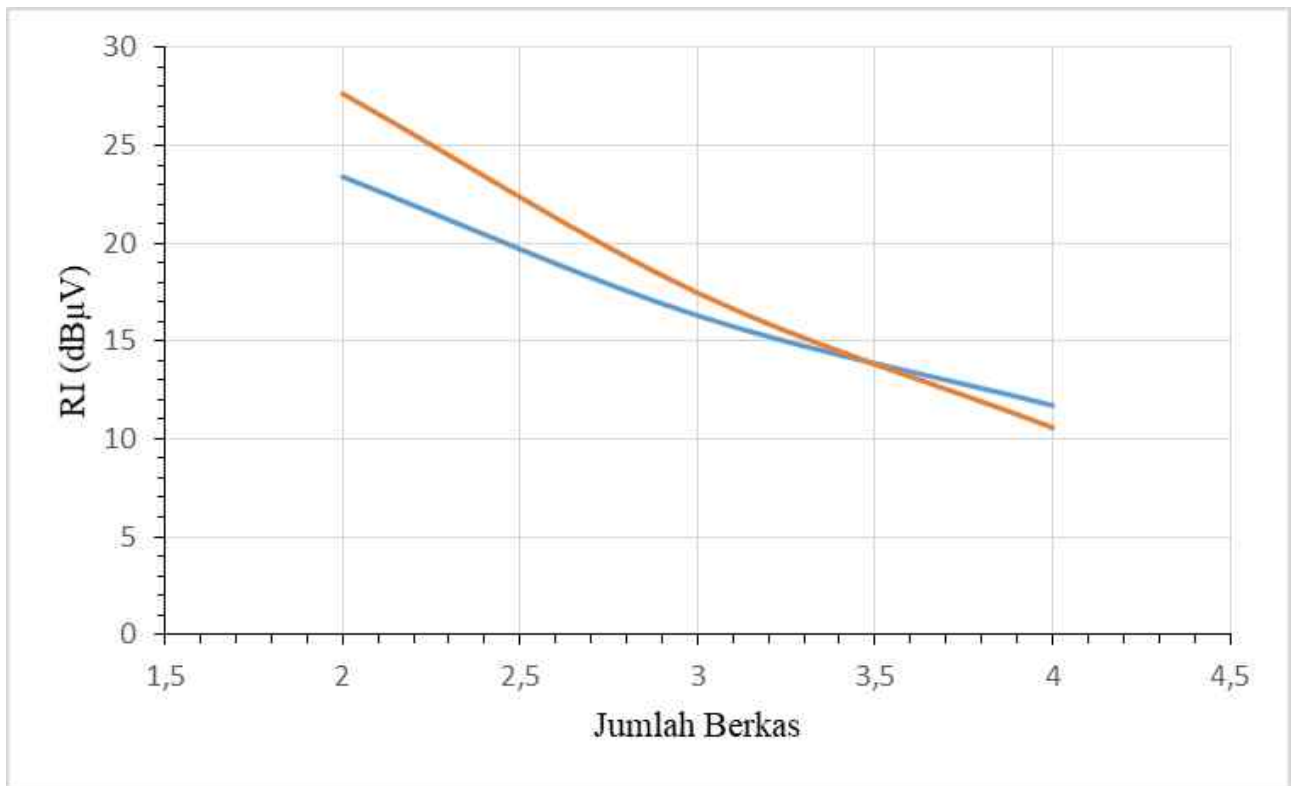

Gambar 4. Hubungan antara jumlah berkas dengan nilai RI 


\subsection{Hubungan jarak antar sub-konduktor dengan nilai AN dan RI}

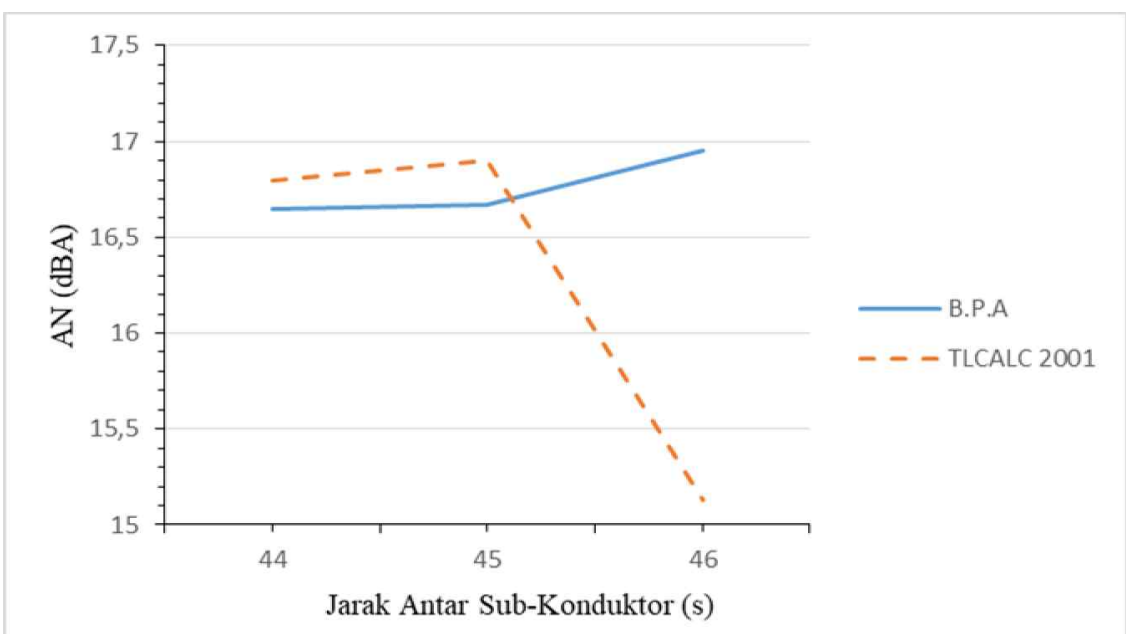

Gambar 5. Hubungan jarak antara sub-konduktor pada jumlah berkas 2 dengan nilai AN

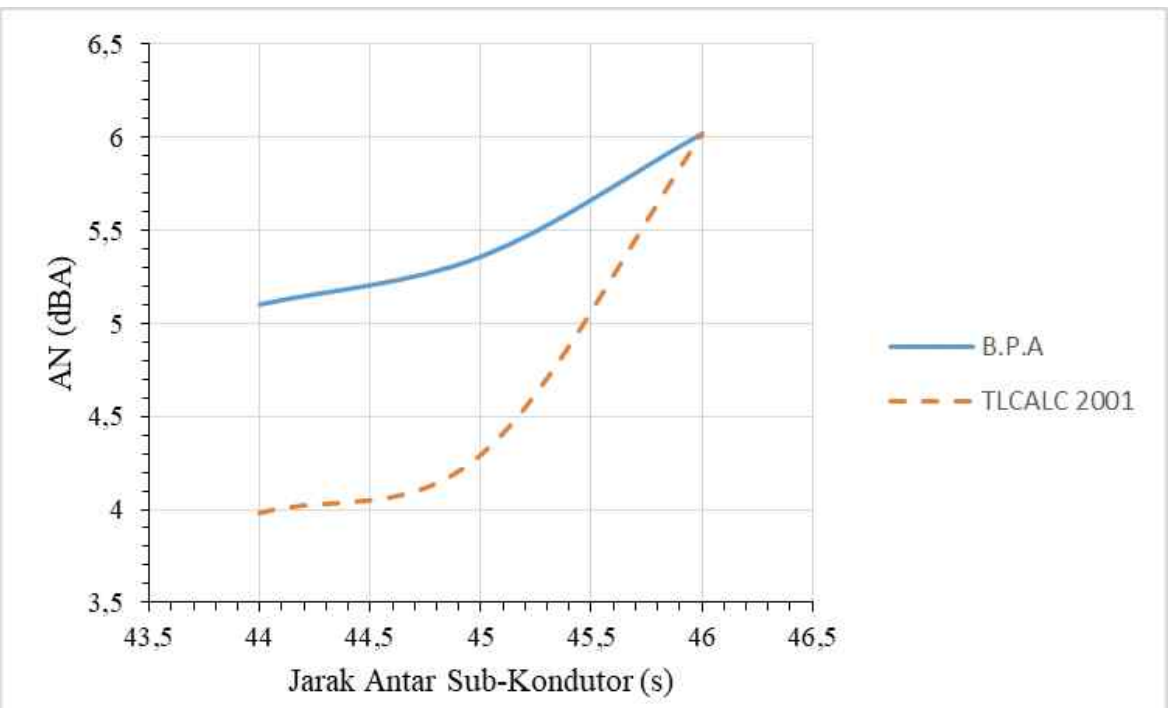

Gambar 6. Hubungan jarak antara sub-konduktor pada jumlah berkas 3 dengan nilai AN 
147 Sonong, Herman Nawir, Fitrawati Suharti, Insan Kamil. Simulasi Pengaruh Variasi Konduktor Berkas Terhadap Gangguan Berisik Dan Radio Interferensi Pada Saluran Udara Tegangan Ekstra Tinggi $275 \mathrm{kV}$

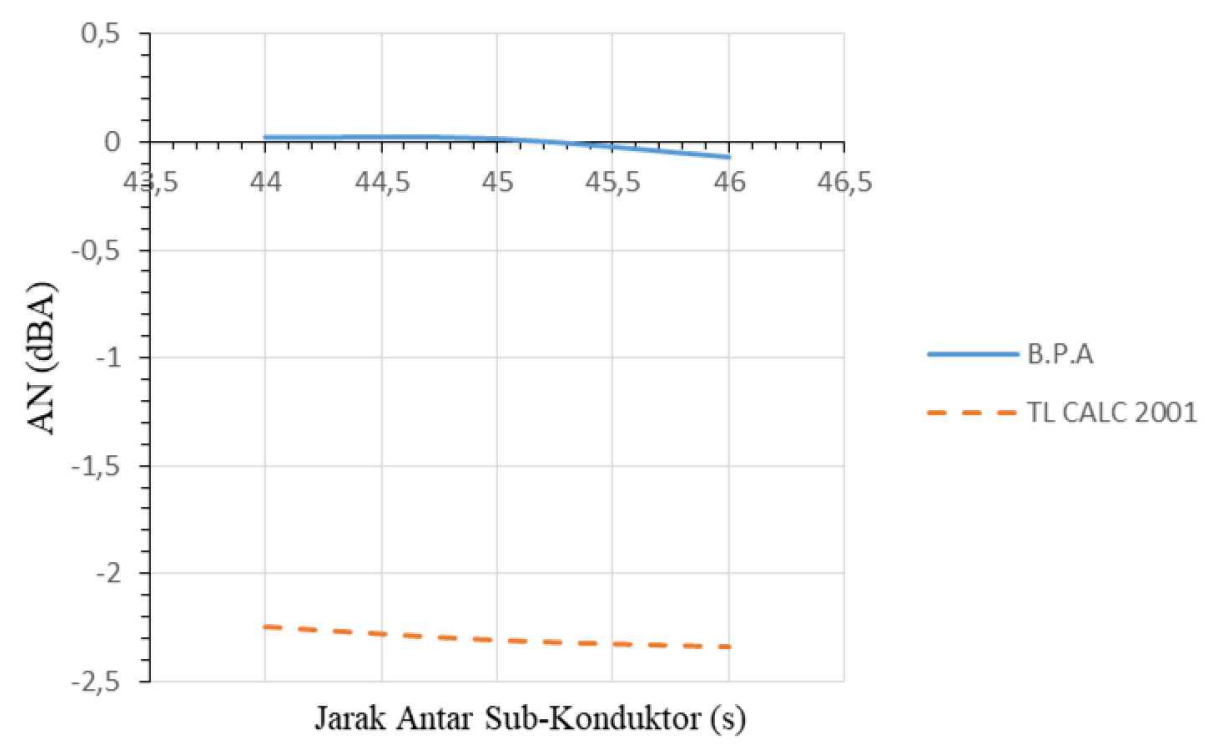

Gambar 7. Hubungan jarak antar sub-konduktor pada jumlah berkas 4 dengan nilai AN

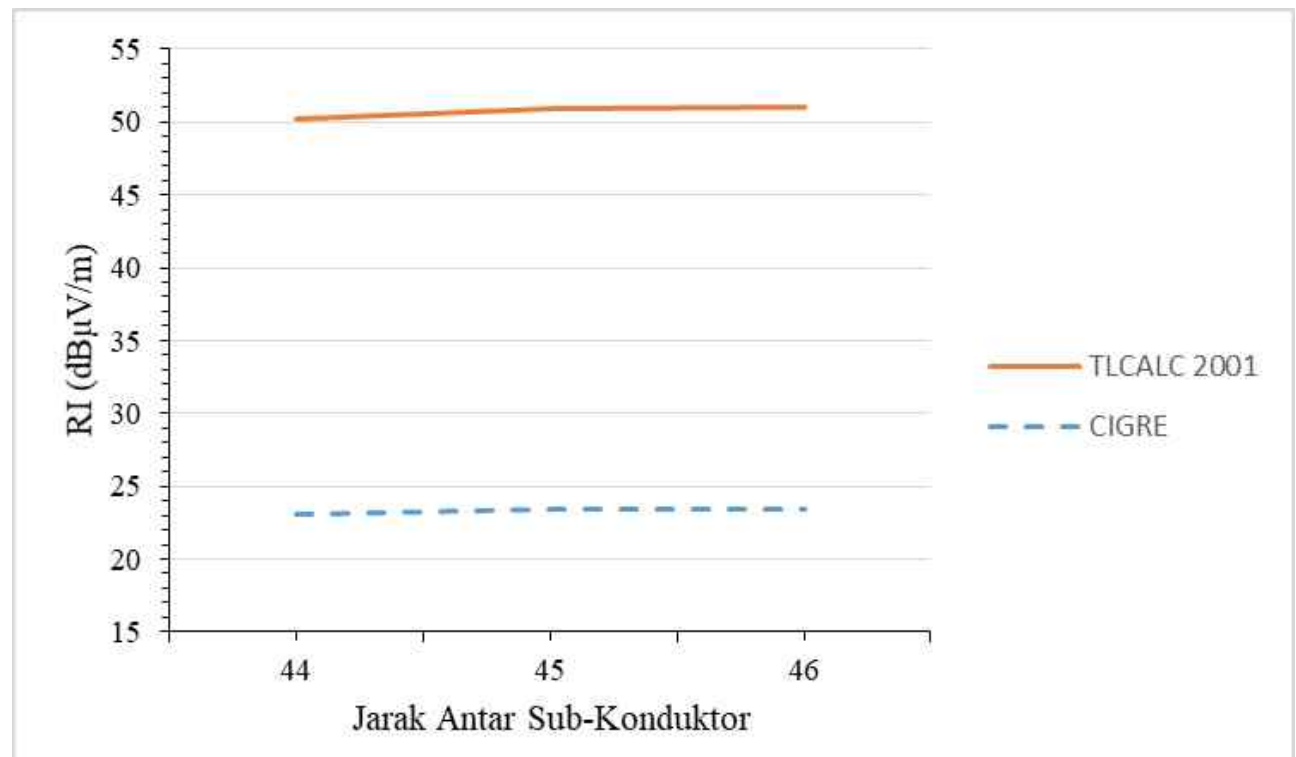

Gambar 8. Hubungan jarak antara sub-konduktor pada jumlah berkas 2 dengan nilai RI 


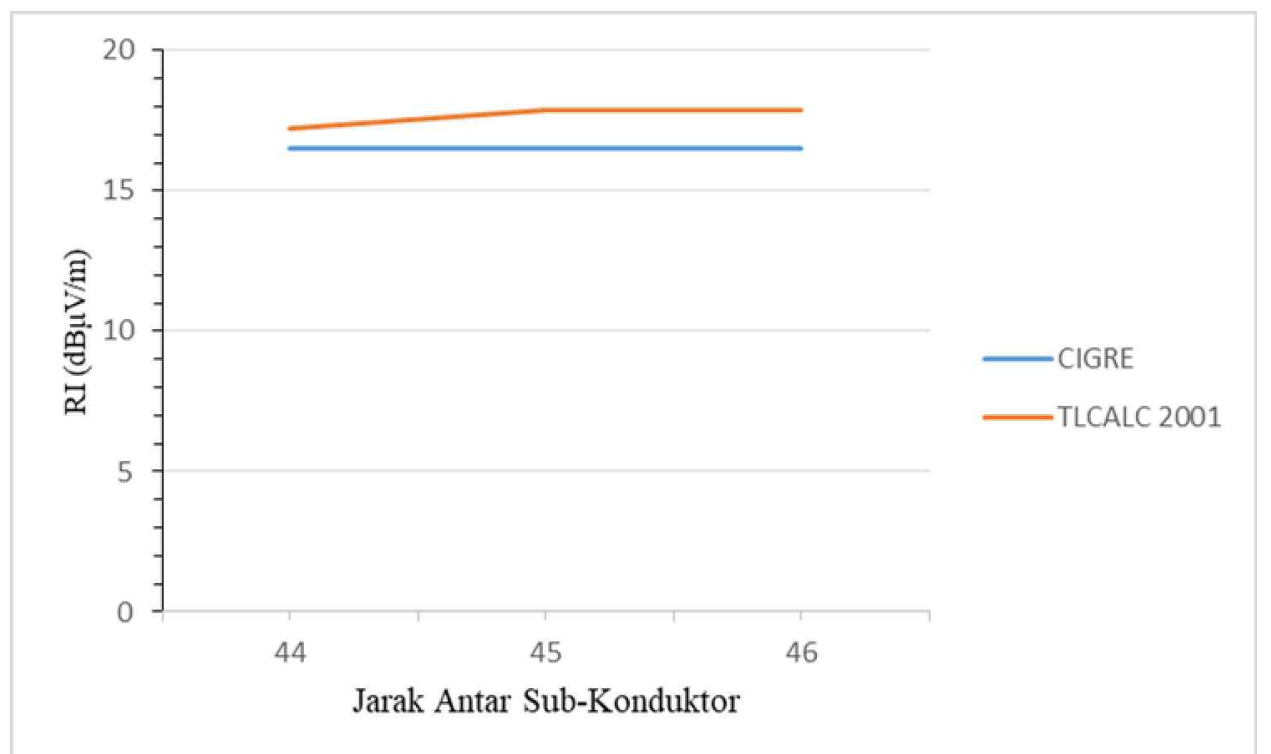

Gambar 9. Hubungan jarak antar sub-konduktor pada jumah berkas 3 dengan nilai RI

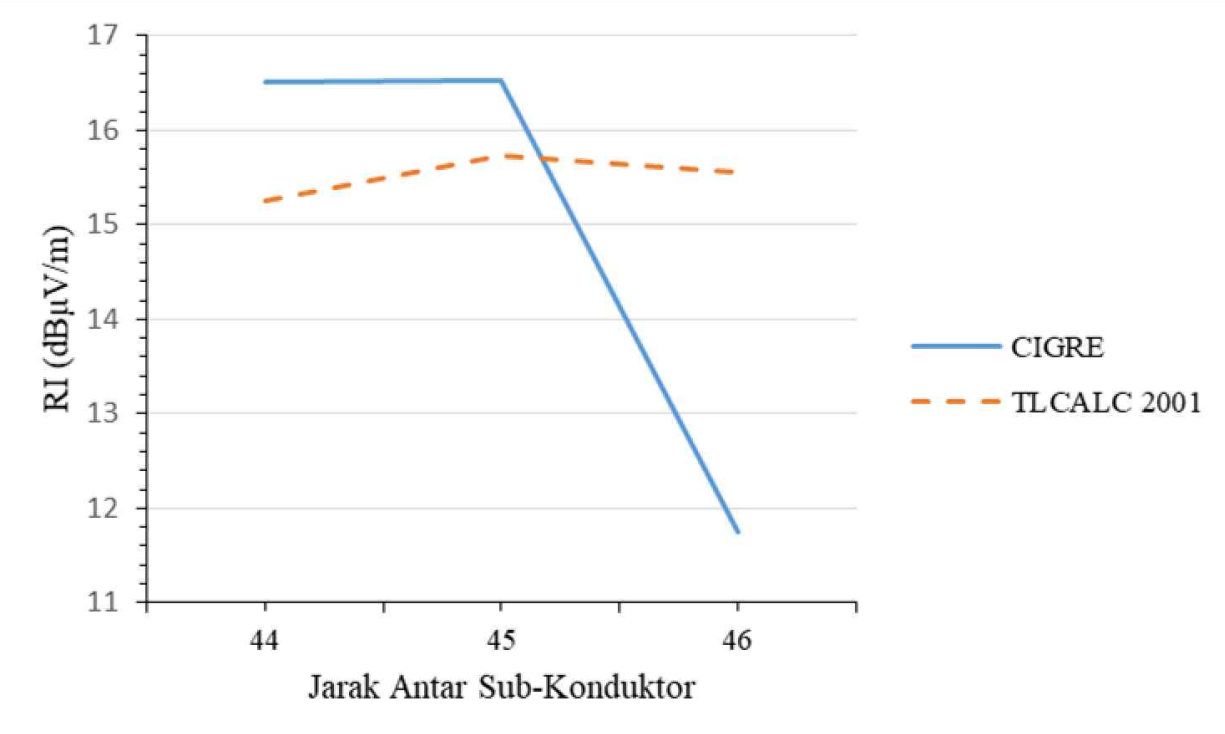

Gambar 10. Hubungan jarak antar sub-konduktor pada jumlah berkas 4 dengan nilai RI

Hasil perhitungan Audible Noise (AN) dengan rumus B.P.A dan TLCALC 2001 pada tabel dan gambar diatas menunjukkan penambahan jumlah berkas (AN) memiliki pengaruh yang cukup besar terhadap penurunan nilai AN. Nilai AN yang ditimbulkan saluran transmisi akan lebih kecil jika jumlah berkas diperbanyak. Nilai AN juga depengaruhi oleh nilai gradient tegangan permukaan konduktor. Besar gradient permukaan juga dipengaruhi oleh konfigurasi konduktor berkas sehingga jika gradient tegangan permukaan konduktor diperkecil maka niali AN yang timbul juga akan semakin kecil.

Hasil perhitungan AN pada saluran transmisi Pomana-Palopo $275 \mathrm{kV}$ menunjukkan skala tingkat rendah $(<52.5 \mathrm{dBA})$ sedangkan jika ditinjau dengan skala tingkat kebisingan SPLN 461-11981, nilai AN menunjukkan skala tingkat tenang $(\mathrm{AN} \leq 20)$. 
149 Sonong, Herman Nawir, Fitrawati Suharti, Insan Kamil. Simulasi Pengaruh Variasi Konduktor Berkas Terhadap Gangguan Berisik Dan Radio Interferensi Pada Saluran Udara Tegangan Ekstra Tinggi 275kV

Hasil perhitungan Radio Interferensi dengan rumus CIGRE dan TLCALC 2001 pada gambar dan table diatas menunjukkan penambahan jumlah berkas memiliki pengaruh cukup besar terhadap penurunan RI. Menimbulkan nilai RI cukup kecil jika nilai jumlah berkas diperbanyak.

Hasil perhitungan RI pada saluran transmisi Pomana - Palopo $275 \mathrm{kV}$ menunjukkan nilai yang masih di bawah $40 \mathrm{~dB} \mu \mathrm{V} / \mathrm{m}$ yang merupakan batas maksimal RI pada jarak $30 \mathrm{~m}$ dari fasa terluar sesuai dengan IEEE Radio Design Guide

\section{KESIMPULAN}

Setelah dilakukan penelitian dan analisis, maka dapat disimpulkan sebagai berikut :

1. Berdasarkan hasil perhitungan Audible Noise $(A N)$ dengan menggunakan data yang diperoleh dari PT Energy Poso, nilai AN pada SUTET 275kV yakni sebesar $16.65 \mathrm{~dB}(\mathrm{~A})$ dengan menggunakan metode BPA dan $16.80 \mathrm{~dB}(\mathrm{~A})$ dengan menggunakan metode TLCALC 2001, jika merujuk pada Kriteria Perry menunjukkan skala tingkat rendah $(<52.5 \mathrm{dBA})$ sedangkan jika ditinjau dengan skala tingkat kebisingan SPLN 461-1-1981, nilai AN menunjukkan skala tingkat tenang $(\mathrm{AN} \leq 20)$ dan tidak mengganggu lingkungan.

2. Berdasarkan hasil perhitungan Radio Interference (RI), nilai RI pada SUTET $275 \mathrm{kV} 23,10 \mathrm{~dB}$ $\mu \mathrm{V} /$ m.dengan menggunakan metode Cigre dan $27,15 \mathrm{~dB} \mu \mathrm{V} / \mathrm{m}$.dengan menggunakan metode TLCALC 2001, jika merujuk pada standar IEEE Radio Noise Design termasuk dalam kategori aman atau nilai RI dibawah batas maksimal $40 \mathrm{~dB} \mu \mathrm{V} / \mathrm{m}$.

3. Adanya penambahan jumlah berkas konduktor dapat menurunkan nilai Audible Noise (AN) beserta Radio Interference (RI).

\section{UCAPAN TERIMA KASIH}

Ucapan terima kasih diberikan kepada Direktorat Jendral Pembelajaran dan Kemahasiswaan Kementrian Riset, Teknologi dan Pendidikan Tinggi Republik Indonesia yang telah mendanai penelitian kami dalam program pekan kretivitas mahasiswa pendanaan tahun 2019.

\section{DAFTAR PUSTAKA}

[1] Amalia, Sarawati. dkk. 2012. Perhitungan Korona, Audible Noise Dan Radio Interference Pada Saluran Udara Tegangan Ekstra Tinggi $500 \mathrm{Kv}$ DenganVariasi Jarak Antar Kawat Dan Jarak Antar Sirkit. Semarang; Universitas Dipenogoro

[2] Arismunandar, A. dan Kuwahara, S., Buku Pegangan Teknik Tenaga Listrik Jilid II : Saluran Transmisi, cetakan kelima, Pradnya Paramita, Jakarta, 1982.

[3] Gultom, Ranolt. 2017. Pengaruh Konfigurasi Konduktor Berkas pada Saluran Transmisi Udara Tegangan Ekstra Tinggi 275 KV Terhadap Gangguan Sinyal Televisi. Sumatera Utara; Universitas Sumatera Utara.

[4] Susilo,Untung. 2007. Analisis Pengaruh Konfigurasi Konduktor Berkas Terhadap Efisiensi, Regulasi Tegangan Dan Korona Pada saluran Udara Tegangan Ekstra Tinggi 500kV.

[5] -----, "Radio Noise Design Guide For High Voltage Transmission Lines", IEEE Transaction on Power Apparatus and System, Vol.PAS-90, no 2, March/April 1971

[6]. ----, "A Comparison of Methods for Calculating Audible Noise of High Voltage Transmission Lines”, IEEE Task Force Report, IEEE Trans. Power Appar.Syst.vol. PAS-101, no. 10, p. 4290, Oct. 198214

[7] K.H.Yang, et all. 2004. "New Enviromentally Friendly Design Program, TLCALC 2001 for High Voltage AC Transmission Lines”, IEEJ Trans.PE, Vol.124, No.1.

[8] ----,SPLN 46-1 Tahun 1981: Pedoman Pembatasan Tingkat Bising, Bagian 1: Tingkat Bising di Lingkungan Kerja.

[9] Firmansyah, A. 2007. Dasar-dasar Pemrograman Matlab. Ilmu Komputer.com, Hal 1. (diakses pada 1 Juli 2019) 